\author{
К. А. Бурлака, С. В. Павлов
}

\title{
MMP8- і HSP70-опосередкована ульцерогенна дія нестероїдних протизапальних засобів за тривалого введення
}

Запорізький державний медичний університет

Ключові слова: HSP70, MMP8, ульцерогенна дія, нестероїдні протизапальні засоби

За оцінками Всесвітньої організації охорони здоров'я, онкологічні захворювання посідають друге місце серед причин людської смертності після серцево-судинних хвороб. В Україні, за даними Національного канцер-реєстру, злоякісні новоутворення шлунково-кишкового тракту (ШКТ) складають найбільшу частку в структурі онкологічної захворюваності населення. Не дивлячись на успіхи у вивченні причин та особливостей онкологічних хвороб, частота захворюваності та смертності від них продовжус зростати. Проблема злоякісного росту є однією з самих актуальних проблем у медицині та біології [1].

Нестероїдні протизапальні засоби (НПЗ3) займають лідируючі позиції за обсягами споживання в світі, що пояснюється високою ефективністю за больового синдрому запального походження. Унікальність цього класу лікарських препаратів обумовлена не тільки протизапальним та знеболюючим ефектом, а також жарознижуючою й антитромботичною дією [2].

Відомо, що тривалий прийом НПЗ3 призводить до утворення ерозій, виразок і різноманітних захворювань шлунка та кишечника [3]. Висловлюється припущення, що зазначені побічні ефекти $є$ не тільки результа-

(c) Колектив авторів, 2021 том пошкодження слизової оболонки під впливом НПЗ3, але й можливим впливом НПЗЗ на гени, які регулюють клітинний цикл. У науковому дослідженні, проведеному в Індії за участю 8 медичних коледжів по всій країні, про шлунково-кишкові ускладнення, пов'язані з прийомом НПЗЗ, повідомлялося в $30,08 \%$ випадків [4]. Також у дослідженні, проведеному в Пакистані за результатами аналізу 820 пацієнтів, які перенесли ендоскопію верхніх відділів ШКТ, було виявлено, що 14,7 \% пацієнтів страждали на виразкову хворобу, пов'язану з прийомом НПЗ3. Відзначено, що виразка дванадцятипалої кишки $(65,3 \%)$ виявлялася частіше, ніж виразка шлунка (42,3\%) [5]. У всіх випадках тривалість прийому та доза НПЗЗ були основними детермінантами тяжкості ускладнень [4]. Ризик ускладнень з боку ШКТ за прийому НПЗ3 збільшується на 2,5$5,0 \%$ у пацієнтів 3 інцидентами 3 боку ШКТ в анамнезі [6]. Крім ускладнень з боку верхніх відділів кишечника, згубна дія НПЗЗ на нижні відділи ШКТ не менш важлива при оцінці ризику цих препаратів. Фактично за останне десятиліття кількість госпіталізацій через ускладнення в нижніх відділах кишечника, пов'язаних з прийомом НПЗ3, збільшилася порівняно 3 патологіями верхніх відділів кишечника [7]. Це підкреслює актуальність пов'язаної з прийомом НПЗЗ ентеропатії, що виявляється у вигляді залізодефіцит- 
ної анемії та гіпоальбумінемії, розладів шлунка та болю в животі. До серйозних ускладнень відносять перфорацію, приховану кровотечу, стриктури кишечника, непрохідність і виразки [8].

В організмі існують молекулярнобіохімічні системи, що спрямовані на інактивацію ксенобіотиків, у тому числі й лікарських засобів, проте відомо, що лікарські препарати здатні змінювати не тільки молекулярні реакції, фрізіологічні функції, а й модулювати генну експресію [9]. Натепер є дані щодо регулюючої дії білків теплового шоку, а саме HSP70 (так званих молекулярних шаперонів) у функціонуванні систем інактивації ксенобіотиків і протидії їхньому токсичному впливу [10].

Разом з цим є дані, що тривалий прийом НПЗЗ призводить до утворення ерозій, виразок i онкологічних захворювань шлунка та кишківника. Висловлюється припущення, що зазначені побічні ефекти є не тільки результатом пошкодження слизової оболонки під впливом НПЗЗ, але й їхнім можливим впливом на гени, які регулюють клітинний цикл [11]. Низкою досліджень встановлено, що, не зважаючи на протизапальну дію НПЗ3, вони здатні за тривалого застосування призводити до суттєвого збільшення вмісту матриксних металопротеїназ, що в свою чергу робить певний внесок у процеси деструкції клітин тканин ШКТ. Матриксні металопротеїнази, особливо MMP8 та MMP9, сприяють розвитку пухлин через їхню безперечну роль у деградації позаклітинного матриксу, яка корелює 3 інвазією ракових клітин i метастазуванням [12]. Паралельно з цими процесами активується синтез білків теплового шоку HSP70 [13]. Встановлено, що HSP70 у великій кількості присутні за онкологічних процесів, забезпечуючи селективну перевагу злоякісних клітин за рахунок пригнічення множинних шляхів апоптозу, регулювання некрозу, обходу програми клітинного старіння, порушення імунітету, стимулювання ангіогенезу та підтримки метастазування. Безпосередня участь HSP70 у більшості ознак раку пояснює феномен ракової «залежності» від HSP70, тісно пов'язуючи виживання та зростання пухлини з експресією HSP70 [14].

Важливо зазначити, що в джерелах літератури $є$ суперечливі дані щодо біологічної ролі HSP70 в умовах онкогенезу. 3 однієї сторони, протеїни HSP70 - важливий ланцюг антиоксидантної системи. Вони захищають клітини від геномо- та цитотоксичних радикалів, беруть участь у деградації окиснених білків і підвищують активність супероксиддисмутази, каталази, опосередковано сприяють інактивації супероксидних аніонів i перекису водню [15, 16]. На думку інших авторів висока антиапоптозна активність цих білків дозволяе розглядати їх промоторами онкогенезу. Показано, що більшість пухлин характеризується конститутивно високим рівнем HSP70 (порівняно з оточуючими тканинами), які забезпечують стійкість пухлин до цитотоксичних факторів, у тому числі хіміотерапевтичних лікарських засобів [17, 18]. Вищезазначене зумовлює актуальність досліджень у цьому напрямі з метою визначення ролі експресії та синтезу білків теплового шоку за онкогенезу.

Крім того, враховуючи роль MMP8 в ініціації онкогенезу та метастазуванні клітин, а також дані щодо можливого впливу НПЗЗ на синтез i концентрацію металопротеїназ, перспективним є більш глибоке вивчення здатності НПЗЗ впливати на вміст 
протеїназ та їхню роль у реалізації небажаних побічних ефектів НПЗЗ.

Мета дослідження - визначення вмісту MMP8 і HSP70 у плазмі крові щурів на тлі тривалого введення НПЗЗ та можливої кореляції з ульцерогенною дією зазначених лікарських засобів.

Матеріали та методи. У дослідженнях були використані 60 щурівсамців лінії Wistar масою 250-400 г, яких отримували з розплідника ДУ «Інститут фармакології та токсикології НАМНУ». Усі експериментальні дослідження проводили з дотриманням основних положень «європейської конвенції про охорону хребетних тварин, що використовуються 3 експериментальною та іншою науковою метою» (Страсбург, 1986 р.) [19]. Догляд, утримання й годування тварин здійснювався згідно з вимогами нормативних документів у стандартних умовах віварію. До початку проведення дослідження комісія 3 питань біоетики ЗДМУ перевірила та погодила протокол дослідження (від 11.11.2019 № 7), а також усі процедури, пов'язані 3 утриманням тварин, гуманним поводженням з ними та використанням в експерименті. Тривалість карантину (акліматизаційного періоду) для всіх тварин становила 14 днів. Протягом карантину проводили щоденний огляд кожної тварини (оцінювали поведінку та загальний стан), двічі на день тварин спостерігали в клітках (оцінювали захворюваність і смертність).

60 лабораторних щурів масою 250400 г були розподілені на чотири групи по 15 тварин у кожній наступним чином: 1 - контрольна (КГ), щури, яким внутрішньочеревинно (в/о) вводили щоденно впродовж 3 міс. розчин натрію хлориду 0,9\%, 2 - щури, яким вводили в/о щоденно впродовж 3 міс. індометацин (AT «Софарма», Болгарія) у дозі 0,6 мг/кг; 3 - щури, яким вводили в/о щоденно впродовж 3 міс. ацетилсаліцилову кислоту (ПрАТ «Дарниця», Україна) у дозі 0,6 мг/кг та 4 група - щури, яким вводили в/о впродовж 3 міс. мелоксикам (Фармекс Груп, Україна) у дозі $0,1 \mathrm{мг/кг.}$

Для встановлення ульцерогенної дії НПЗ3 оцінювали ступінь пошкодження шлунка та кишечника в балах: 0 балів - відсутність пошкодження, 1 бал - від 1 до 3 невеликих виразок, 2 бали - більше 3 невеликих виразок, 3 бали - виразка значних розмірів і декілька невеликих виразок, 4 бали - декілька великих виразок, 5 балів - перфоративна виразка. Крім того, симптоми, які передують виникненню деструкцій у ШКТ та свідчать про певні трофічні порушення в його слизовій оболонці (набряк, гіперемія, крововилив), оцінювали в 0,5 бала [20].

Для отримання плазми цільну кров центрифугували та зберігали за температури $-86{ }^{\circ} \mathrm{C}$. У дослідних зразках визначали кількість HSP70 rats (Biomedica) - (Hycult Biotech, Нідерланди), MMP8 (Matrix Metalloproteinase-8, Elabscience Biotechnology Inc., USA). Кількісний аналіз здійснювали імуноферментним методом, що базується на використанні «сендвіч»-варіанту твердофазного імуноферментного аналізу зі застосуванням імуноферментного комплексу ImmunoChem-2100 (США). Аналіз проводили в 96-лункових мікропланшетах, дно яких було вкрите моноклональними антитілами до відповідного молекулярного маркера. Зразки плазми вносили до відповідних лунок мікропланшетів та інкубували протягом необхідного часу. Після етапів промивання реагенти видаляли з лунок мікроплан- 
шетів, а також вносили додаткові реагенти, які згодом вимивалися. Аналіз проводили 3 додаванням колориметричного реагенту, результуючий сигнал вимірювали спектрофотометрично за 450 нм.

Статистичну обробку результатів проводили з використанням програми «STATISTICA ${ }^{\circledR}$ for Windows 6.0» (StatSoft Inc., № AXXR712D833214FAN5). Достовірність відмінностей проводили з використанням t-критерію Стьюдента. При проведенні кореляційного аналізу використовували критерій Spearman. Достовірними розбіжності та наявність кореляційного зв'язку вважали при рівні значущості $\mathrm{p}<0,05$. [21].

Результати та їх обговорення. Макроскопічне дослідження слизових оболонок ШКТ показало наявність ульцерогенної дії досліджуваних лікарських засобів за їхнього тривалого введення, особливо індометацину. Застосування мелоксикаму в дозі 0,1 мг/кг (табл. 1), практично не викликало уражень слизових оболонок, було зафіксовано лише поодинокі ураження та низький ступінь пошкоджень у 40 \% тварин.

У плазмі крові експериментальних тварин реєстрували статистично вірогідне збільшення вміту MMP8 в усіх експериментальних групах (табл. 2). Відомо, що ефекти НПЗЗ безпосередньо пов'язані 3 їхньою здатністю зменшувати гіперпродукцію інтерлейкінів, фактора некрозу пухлин, активність матриксних металопротеїназ, продуктів пероксидації. Однак на тлі тривалого застосування при розвитку небажаних побічних ефектів, насамперед ульцерогенної дії, відбувається інтенсифікація в уражених тканинах процесів вільнорадикального окиснення та активація матриксних металопротеїназ, насамперед MMP4, MMP8 i MMP9. Це цілком збігається з нашими експериментальними дослідженнями. Так, було встановлено значне підвищення вмісту MMP8 у плазмі тварин, які отримували індометацин, у середньому - на $86 \%$, ацетилсаліцилову кислоту - на $79 \%$ i мелоксикам - на 66 \% (табл. 2).

Враховуючи низку досліджень, в яких показано здатність НПЗ3 викликати онкологічні захворювання кишківника за тривалого застосування, отримані нами дані стосовно MMP8 можуть деякою мірою пояснити вищезазначений побічний ефект. Так, матриксні металопротеїнази відіграють важливу роль у прогресуванні колоректального раку, беручи участь у руйнуванні екстрацелюлярного матриксу, ангіогенезі

Таблиця 1

Ульцерогенна дія індометацину, ацетилсаліцилової кислоти та мелоксикалу за улов тривалого введення

\begin{tabular}{|l|c|c|}
\hline \multicolumn{1}{|c|}{ Експериментальна група } & $\begin{array}{c}\text { Тварини з пошкоджен- } \\
\text { нями шлунково-кишко- } \\
\text { вого тракту, \% }\end{array}$ & $\begin{array}{c}\text { Ступінь пошкодження } \\
\text { шлунково-кишкового } \\
\text { тракту, бал }\end{array}$ \\
\hline $\begin{array}{l}\text { Контрольна група тварин, } \\
\text { 0,9\% NaCl, } \mathrm{n}=15\end{array}$ & 0 & $14,70 \pm 0,05^{\star}$ \\
\hline Індометацин, 0,6 мг/кг, $\mathrm{n}=15$ & 100 & $7,10 \pm 1,0^{\star}$ \\
\hline $\begin{array}{l}\text { Ацетилсаліцилова кислота, } \\
\text { 0,6 мг/кг, } \mathrm{n}=15\end{array}$ & 85 & $0,60 \pm 0,01^{\star}$ \\
\hline Мелоксикам, 0,1 мг/кг, $\mathrm{n}=15$ & 40 & \\
\hline
\end{tabular}

Примітка. Тут і в табл. 2: *p < 0,05 відносно контрольной групи тварин, $n$ - кількість тварин у групі. 
Вліст МMP8 і НSP70 у плазмі крові шурів за тривалого введення нестероїдних протизапальних засобів ( $(\mathrm{m} \pm \mathrm{m})$

\begin{tabular}{|l|c|c|}
\hline \multicolumn{1}{|c|}{ Експериментальна група } & MMP8, ng/mI & HSP70, ng/ml \\
\hline $\begin{array}{l}\text { Контрольна група тварин, } \\
0,9 \% \mathrm{NaCl,} \mathrm{n}=15\end{array}$ & $0,11 \pm 0,03$ & $3,80 \pm 0,42$ \\
\hline Індометацин, 0,6 мг/кг, $\mathrm{n}=15$ & $0,82 \pm 0,10^{\star}$ & $14,90 \pm 0,62^{\star}$ \\
\hline $\begin{array}{l}\text { Ацетилсаліцилова кислота, } \\
\text { 0,6 мг/кг, } \mathrm{n}=15\end{array}$ & $0,52 \pm 0,14^{\star}$ & $10,50 \pm 0,8^{\star}$ \\
\hline Мелоксикам, 0,1 мг/кг, $\mathrm{n}=15$ & $0,32 \pm 0,08^{\star}$ & $7,30 \pm 0,27^{\star}$ \\
\hline
\end{tabular}

пухлини; крім того, вони взаємодіють з факторами росту та їхніми рецепторами, медіаторами апоптозу та молекулами клітинної адгезії [22, 23]. Саме деградація базальної мембрани та строми - це необхідний механізм до запуску процесів онкогенезу та метастазування. Багато пухлин характеризуються локально та системно збільшеним рівнем матриксних металопротеїназ, здатних руйнувати білкові молекули матриксу. Крім того, більшість матриксних металопротеїназ секретується не онкозміненими клітинами, а оточенням навколо пухлини. Оскільки у формуванні пухлин важливу роль відіграє стромальне оточуюче середовище, то саме MMP9, MMP4 (та особливо MMP8) здатні змінювати та ініціювати онкогенез на початкових стадіях [23].

Крім того, було зареєстровано також підвищення вмісту HSP70 у плазмі крові. Ці зміни були односпрямованими з вмістом MMP8 і в цілому з ульцерогенною дією НПЗЗ. На нашу думку, подібне підвищення вмісту HSP70 обумовлено двома протилежними процесами, що узгоджується з іншими дослідженнями. На тлі ульцерогенної дії НПЗЗ активується система клітинних шаперонів, які здатні забезпечити фолдинг білків і запобігати процесам їхньої денатурації. HSP70 збільшують виживання клітин після безлічі стресів, включаючи підвищену температуру, гіпоксію, окиснювальний стрес, зміну рH, вплив важких металів та ін. Цей вплив на виживання висвітлено в здатності HSP70 нейтралізувати токсичність денатурованих i неправильно згорнутих білків, які накопичуються під час цитодеструкції. HSP70 за рахунок антиоксидантної дії, а також завдяки спроможності пригнічувати активацію стресових кіназ сімейства SAPK/JNK як одного 3 основних ранніх тригерів апоптозу, можуть чинити проонкогенну дію та підсилювати ефекти матриксних металопротеїназ [24].

Важливо зазначити, що математичний аналіз даних вмісту MMP8 i HSP70 показав позитивний кореляційний зв'язок середньої сили (індометацин, $r=0,62$ та $r=0,49$ відповідно; ацетилсаліцилова кислота, $r=0,57$ та $r=0,60$ відповідно; мелоксикам, $\mathrm{r}=0,50$ та $\mathrm{r}=0,56$ відповідно) між вмістом цих маркерів та ступенем пошкодження ШКТ у щурів.

Таким чином, проведеними експериментальними дослідженнями було встановлено здатність НПЗЗ за умов тривалого введення підвищувати вміст MMP8 і HSP70 у плазмі крові щурів. Їхня концентрація позитивно корелювала 3 ульцерогенною дією, 
вираженість якої в дослідних препаратів зменшувалась у ряду - індометацин, ацетилсаліцилова кислота, мелоксикам (де індометацин - лікарський засобів 3 максимальними побічними ефектами, мелоксикам - 3 мінімальними). Встановлені патобіохімічні зміни можуть бути як ланцюгом розвитку цитодеструкції у відповідь на тривале введення НПЗ3, а також і чинниками розвитку онкологічних захворювань ШКТ, тому перспективним є подальше вивчення молекулярних аспектів небажаних побічних ефектів для розробки ефективних підходів до підвищення профілю безпечності НПз3.

\section{Висновки}

1. Встановлено здатність НПЗЗ, а саме, індометацину, ацетилсаліцилової кислоти та мелоксикаму призводити до збільшення вмісту MMP8 i HSP70 у плазмі крові щурів на тлі їхнього тривалого введення.

2. Показано наявність позитивного кореляційного зв'язку середньої сили між вмістом MMP8 і HSP70 зі ступенем пошкодження ШКТ у щурів.

3. Отримані результати свідчать про можливий MMP8- i HSP70-опосередкований механізм ульцерогенної дії НПЗ3 за умов тривалого введення.

1. NORDCAN: Cancer Incidence, Mortality, Prevalence and Survival in the Nordic Countries, Version 7.1. Association of the Nordic Cancer Registries. G. F. J. Engholm, N. Christensen, A. M. T. Kejs et al. Danish Cancer Society. August 5, 2015.

2. McGettigan P., Henry D. Use of non-steroidal anti-inflammatory drugs that elevate cardiovascular risk: an examination of sales and essential medicines lists in low-, middle-, and high-income countries. PLoS Med. 2013. № 10 (2). P. 78-83.

3. Mechanisms of Damage to the Gastrointestinal Tract From Nonsteroidal Anti-Inflammatory Drugs. I. Bjarnason, C. Scarpignato, E. Holmgren et al. Gastroenterology. 2018. № 154 (3). P. 500-514.

4. Cross-Sectional Study for Prevalence of Non-Steroidal Anti-Inflammatory Drug-Induced Gastrointestinal Cardiac and Renal Complications in India: Interim Report. S. Chatterjee, G. P. Dureja, G. Kadhe et al. Gastroenterology Res. 2015. № 8 (3-4). P. 216-221.

5. Frequency of NSAID induced peptic ulcer disease. S. Hamid, J. Yakoob, W. Jafri et al. J. Pak. Med. Assoc. 2006. № 56 (5). P. 218-222.

6. Guidelines for the appropriate use of non-steroidal anti-inflammatory drugs, cyclo-oxygenase2-specific inhibitors and proton pump inhibitors in patients requiring chronic anti-inflammatory therapy. R. W. Dubois, G. Y. Melmed, J. M. Henning et al. Aliment. Pharmacol. Ther. 2004. № 19 (2). P. 197-208.

7. Sostres C., Gargallo C. J., Lanas A. Nonsteroidal anti-inflammatory drugs and upper and lower gastrointestinal mucosal damage. Arthritis Res. Ther. 2013. № 15 (Suppl 3). P. 3-5.

8. Non-steroidal anti-inflammatory drug-induced enteropathy. S. J. Shin, C. K. Noh, S. G. Lim et al. Intest. Res. 2017. № 15 (4). P. 446-455.

9. Non-corticosteroid immunosuppressive medications for steroid-sensitive nephrotic syndrome in children. N. G. Larkins, I. D. Liu, N. S. Willis et al. Cochrane Database Syst Rev. 2020. № 16.4 (4). P. 22.

10. Genetic, Epigenetic, and Steroidogenic Modulation Mechanisms in Endometriosis. A. Zubrzycka, M. Zubrzycki, E. Perdas et al. J Clin Med. 2020. № 9 (5). P. 1309.

11. Gielisse E. A. R., Kuyvenhoven. J. P. Follow-up endoscopy for benign-appearing gastric ulcers has no additive value in detecting malignancy: It is time to individualise surveillance endoscopy. Gastric Cancer. 2015. № 18 (4). P. 803-809.

12. The Behavior of Matrix Metalloproteinases and Their Inhibitors in Colorectal Cancer. L. Herszenyi, I. Hritz, G. Lakatos et al. Int J. Mol Sci. 2012. № 13. P. 13240-13263.

13. Молекулярно-біохімічні механізми HSP70-опосередкованої цитопротекції в умовах патологій ішемічного генезу. С. В. Павлов, І. Ф. Бєленічев, Ю. В. Нікітчєнко и др. Вісник проблем біології і медицини. 2017. Вип. 3. Т. 1 (137). С. 61-67.

14. Heat shock proteins in cancer: Chaperones of tumorigenesis. S. Calderwood, A. Khaleque, U. B. Sawyer et al. Trends Biochem. Sci. 2006. № 31. P. 164-172.

15. The molecular chaperone Hsp70 promotes the proteolytic removal of oxidatively damaged proteins by the proteasome. S. Reeg, T. Jung, J. P. Castro et al. Free Radic. Biol. Med. 2016. № 99. P. $153-166$. 
16. Protein transport into the human endoplasmic reticulum. J. Dudek, S. Pfeffer, P. H. Lee et al. J. Mol. Biol. 2015. № 427. P. 1159-1175.

17. Targeting cell survival proteins for cancer cell death. M. K. Pandey, S. Prasad, A. K. Tyagi et al. Pharmaceuticals. 2016. № 9. P. 11.

18. Targeting Hsp70: A possible therapy for cancer. S. Kumar, J. Stokes, U. P. Singh et al. Cancer Lett. 2016. № 374. Р. 156-166.

19. Європейська конвенція про захист хребетних тварин, що використовуються для дослідницьких або інших наукових цілей від18.03.1986: Верховна Рада України, офіційний веб-портал: Міжнародні документи (Рада Європи).

20. Доклінічні дослідження лікарських засобів (методичні рекомендації); за ред. О. В. Стефанова. Київ : ВД «Авіцена», 2002. 527 с.

21. Лапач С. Н., Чубенко А. В., Бабич П. Н. Статистические методы в медико-биологических исследованиях с использованием EXCEL. Киев : «МОРИОН», 2002. 640 с.

22. Колесник А. П., Паламарчук И. Д., Сидоренко А. М. Молекулярные маркеры прогрессирования колоректального рака. Онкология. 2006. № 1. Т. 8. С. 13-17.

23. Regorafenib induces adaptive resistance of colorectal cancer cells via inhibition of vascular endothelial growth factor receptor. H. Nagano, N. Yamagishi et al. J. Med. Invest. 2017. № 64 (3.4). P. 262-265.

24. Heat Shock Proteins delivered with a virus vector can protect cardiac cells against apoptotic as well as against thermal or hypoxic stress. B. K. Brar, A. Stephanou, M. J. Wagstaff et al. J. Mol. Cell. Cardiol. 1999. № 31. P. 135-146.

\section{К. А. Бурлака, С. В. Павлов \\ MMP8- і HSP70-опосередкована ульцерогенна дія нестероїдних протизапальних засобів за тривалого введення}

У статті розглянуто вплив нестероїдних протизапальних засобів (НПЗ3), а саме індометацину, ацетилсаліцилової кислоти та мелоксикаму, за їхнього тривалого введення на вміст MMP8 і HSP70 у плазмі крові щурів. Тривалий прийом НПЗ3, як відомо, призводить до утворення ерозій, виразок й інших захворювань шлунка та кишечника. Висловлюється припущення, що дані побічні ефекти є не тільки результатом пошкодження слизової оболонки НПЗЗ, але й можливого впливу НПЗЗ на гени, які регулюють клітинний цикл.

Мета дослідження - вивчення вмісту MMP8 і HSP70 у плазмі крові щурів за тривалого введення НПЗ3 та можливої кореляції цих показників з ульцерогенною дією зазначених лікарських засобів.

Дослідження проведено на 60 лабораторних щурах масою 250-400 г, які були розподілені на чотири групи по 15 тварин: 1 - контрольна (КГ), щури, яким вводили щоденно впродовж 3 міс. розчин натрію хлориду 0,9 \%, 2 - щури, яким вводили щоденно індометацин протягом 3 міс. у дозі 0,6 мг/кг, 3 - щури, яким вводили щоденно протягом 3 міс. ацетилсаліцилову кислоту в дозі 0,6 мг/кг та 4 група - щури, яким вводили щоденно протягом 3 міс. мелоксикам у дозі 0,1 мг/кг.

У результаті проведених досліджень виявлено значне підвищення вмісту ММР8 у плазмі тварин, які отримували індометацин, у середньому на $86 \%$, ацетилсаліцилову кислоту - на $79 \%$ і мелоксикам - на 66 \%. А також було зареєстровано підвищення вмісту HSP70 у всіх групах дослідних тварин.

Математичний аналіз показав наявність позитивного кореляційного зв'язку середньої сили між вмістом досліджених маркерів, MMP8 і HSP70, і ступенем пошкодження шлунково-кишкового тракту в щурів.

Отримані результати свідчать про можливий MMP8- і HSP70-опосередкований механізм ульцерогенної дії НПЗ3, який також може бути одним з молекулярних механізмів ініціації онкогенезу в шлунково-кишкового тракті.

\section{Ключові слова: HSP70, MMP8, ульцерогенна дія, нестероїдні протизапальні засоби}

\section{К. А. Бурлака, С. В. Павлов}

\section{MMP8- и HSP70-опосредованное ульцерогенное действие нестероидных противовоспалительных средств при длительном введении}

В статье рассмотрено влияние длительного введения нестероидных противовоспалительных средств (НПВС), а именно индометацина, ацетилсалициловой кислоты и мелоксикама, на содержание MMP8 и HSP70 в плазме крови крыс. Длительный прием НПВС, как известно, приводит к образованию эрозий, язв и других заболеваний желудка и кишечника. Высказывается предположение, что данные побочные эффекты являются не только результатом повреждения слизистой под влиянием НПВС, но и возможным влиянием НПВС на гены, регулирующие клеточный цикл.

Цель исследования - изучить содержания MMP8 и HSP 70 в плазме крови крыс на фоне длительного введения НПВС и возможную корреляцию этих показателей с ульцерогенным действием указанных лекарственных средств. 
Исследование проведено на 60 лабораторных крысах массой 250-400 г, которые были распределены на четыре группы по 15 животных, а именно: 1 - контрольная, крысы, которым внутрибрюшинно (в/б) вводили ежедневно в течение 3 мес. раствор натрия хлорида 0,9 \%, 2 - крысы, которым в/б вводили ежедневно в течение 3 мес. индометацин в дозе 0,6 мг/кг, 3 - крысы, которым в/б вводили ежедневно в течение 3 мес. ацетилсалициловую кислоту в дозе 0,6 мг/кг и 4 группа крысы, которым в/б вводили ежедневно в течение 3 мес. мелоксикам в дозе 0,1 мг/кг.

В результате проведенного исследования установлено, что на фоне длительного применения НПВС отмечается значительное повышение содержания MMP8 в плазме животных, получавших индометацин, в среднем на 86 \%, ацетилсалициловую кислоту - на 79 \% и мелоксикам - на $66 \%$. Было также зарегистрировано повышение содержания HSP70 у животных всех групп.

Математический анализ показал наличие положительной корреляционной связи средней силы между содержанием исследованных маркеров, MMP8 и HSP70, и степенью повреждения желудочнокишечного тракта у крыс.

Полученные результаты свидетельствуют о возможном MMP8- и HSP70-опосредованном механизме ульцерогенного действия НПВС, который также может быть одним из молекулярных механизмов инициации онкогенеза в желудочно-кишечном тракте.

Ключевые слова: HSP70, MMP8, ульцерогенное действие, нестероидные противовоспалительные лекарственные средства

\section{K. A. Burlaka, S. V. Pavlov}

MMP8- and HSP70-mediated ulcerogenic effect of non-steroidal antiinflammatory drugs under their long term administration

The article discusses the ability of NSAIDs, namely indomethacin, acetylsalicylic acid and meloxicam affect the content of MMP8 and HSP70 in the blood plasma of rats under their long-term administration. Long-term use of NSAIDs, as known, leads to the formation of erosions, ulcers and various diseases of the stomach and intestines. It is suggested that these side effects are not only the result of the mucous membrane damage under the influence of NSAIDs, but also the possible action of NSAIDs on genes that regulate the cell cycle.

The aim of the study was to determine the content of MMP8 and HSP 70 in the blood plasma of rats after prolonged administration of NSAIDs and to evaluate their possible correlation with the ulcerogenic effect of these drugs.

The studies were carried out on 60 laboratory rats weighing 250-400 g, which were divided into four groups of 15 animals: 1 - control, animals were injected i. p. daily for 3 months with sodium chloride $0.9 \%$, 2 - rats were injected i. p. daily with indomethacin for 3 months at a dose of $0.6 \mathrm{mg} / \mathrm{kg}, 3$ - rats were injected i. p. daily for 3 months with acetylsalicylic acid for 3 months at a dose of $0.6 \mathrm{mg} / \mathrm{kg}$ and the 4 group - rats, which were injected i. p. daily with meloxicam at a dose of $0.1 \mathrm{mg} / \mathrm{kg}$ for 3 months.

It was found that long-term use of NSAIDs with the development of undesirable side effects, primarily ulcerogenic action, an activation of matrix metalloproteinase MMP8 occurs. There was a significant increase in the content of MMP8 in the plasma of animals treated with indomethacin by an average of $86 \%$, acetylsalicylic acid - $79 \%$ and meloxicam - by $66 \%$. An increase in HSP70 was also recorded in all groups.

Mathematical analysis shows the presence of a positive medium strenght correlation between these markers and the degree of gastrointestinal damage in rats.

The results obtained indicate a possible MMP8- and HSP70-mediated mechanism of ulcerogenic action of NSAIDs, which may also be a molecular chain of initiation of gastrointestinal oncogenesis.

Key words: HSP70, MMP8, ulcerogenic action, nonsteroidal anti-inflammatory drugs

Надійшла: 20 жовтня 2021 р.

Прийнята до друку: 8 грудня 2021 р.

Контактна особа: Павлов С. В., доктор біологічних наук, професор, кафедра клінічної лабораторної діагностики, Запорізький державний медичний університет, буд. 26, просп. Маяковського, м. Запоріжжя, 69035. Тел.: + 380617643885. 